\title{
ACTUAL HRM CHALLENGES AND INNOVATIVE TRENDS AS ESSENTIAL FACTORS IN BUSINESS ENTERPRISE SUCCESS
}

\author{
АКТУАЛЬНІ ПРОБЛЕМИ ТА ІННОВАЦІЙНІ ТРЕНДИ \\ РОЗВИТКУ НR МЕНЕДЖМЕНТУ, ЯК ОСНОВНІ ФАКТОРИ \\ УСПІХУ СУБ'ЄКТІВ БІЗНЕСУ
}

\author{
Semeiko Anna \\ English Language Tutor, \\ Company "I-TutorGroup", \\ Kyiv, Ukraine \\ Семейко А.C. \\ викладач англійської мови, \\ Компанія "I-TutorGroup", \\ Київ, Україна
}

\begin{abstract}
Human resource management has become very important as a tool for organizational success. To perform well, it has to achieve its objectives and goals. It has to satisfy the demands of stakeholders and staff and the regulatory authorities. Consequently, reasonable HR management is one of the main factors to define the stability and success of the business. The article deals with the contemporary issues what HR departments face nowadays, attempts to understand and analyze the challenges existing and affecting their functioning, presents the significance of prudent human resource management and also reveals the best practices and trends which are to support the prosperity of any organization in the modern and digitized age. It is shown the importance of alignment the company's strategy and vision with the labor thinking to progress within the time.
\end{abstract}

Key words: Human Resource Management, innovative trends, business success, business strategy, challenges, performanceassessment, relevant resources.

В сучасному середовищі, управління людськими ресурсами $є$ дуже важливим інструментом успіху організації, а розумне управління персоналом $\epsilon$ одним з головних фракторів для визначення стабільності та успіху бізнесу. Управління людськими ресурсами є інструментом досягнення цілей і завдань будь-якої організації. У статті наголошено, що ролі та обов'язки відділу кадрів змінюються в сучасному бізнесі через швидко зростаючу конкуренцію та гнучке середовище. Автор наголошує, що вкрай важливо, щоб цілі співробітників будь якої компанії співпадали з стратегією цього бізнесу - це приведе до успіху організації на довгостроковий період. Ця стаття присвячена доведенню, що HR менеджмент має дуже великий вплив на успіх суб'єктів бізнесу, а також основним проблемам управління трудовими ресурсами сьогодні, в умовах швидкої зміни навколишнього середовища. Віддана важливість пошуку інноваційних трендів на прикладі іноземних компаній, які успішно існують багато років на міжнародному ринку. У статті розглядаються сучасні проблеми, з якими стикаються нині кадрові відділи, спроби зрозуміти та проаналізувати існуючі проблеми та вплинути на їх фрункціонування, представлено значення розсудливого управління людськими ресурсами, а також розкрито найкращі практики та тенденції, що сприяють процвітанню будь-якої організації в сучасний та цифрровий вік. Показано важливість узгодження стратегії та бачення компанії з трудовим мисленням для прогресу протягом часу. Всі чі фрактори та деталі необхідно враховувати при керівництві персоналу у будь якому бізнесі задля досягнення успіху. Стаття визначає важливість впливу трудових ресурсів компанії на її успіх через розумне управління з боку кадрового менеджменту. Так, основні фрактори, які значно впливають на розвиток бізнесу цілком пов'язані зі швидкою зміною середовища і неспроможність HR менеджменту швидко реагувати на ці зміни. Розвиток цисррових інструментів для вступу до лідерських позицій на ринку має бути пріоритетом для організацій. Це забезпечить бізнес стратегічними планами цифррової трансфрормації та організаційною культурою, яка ії підтримуватиме. Автор вважає, що менеджери HR департаментів повинні щільно слідкувати за тенденціями розвитку в таких напрямках як: наймання відповідних робітників, їх розвиток, впровадження певних метрік для визначення якості праці всіх трудових ресурсів компанії.

Ключові слова: управління персоналом, інноваційні тенденції, успіх у бізнесі, бізнес-стратегія, проблеми, оцінка ефективності, відповідні ресурси. 
Управление человеческими ресурсами является очень важным инструментом успеха организации. Необходимо достигать поставленных целей и задач, чтобы добиться успеха. Также департамент управления человеческими ресурсами должен удовлетворять требования предпринимателей, персонала и регулирующих органов. Следовательно, разумное управление персоналом является одним из основных факторов, определяющих стабильность и успіх бизнеса. В статье рассматриваются современные проблемы, с которыми сталкиваются отделы кадров в настоящее время, предпринимаются попытки понять и проанализировать существующие проблемы, влияющие на их функционирование, представлена важность розумного управления человеческими ресурсами, а также раскрыты лучшие практики и мировые тенденции, способствующие процветанию любой организации в современную и цифровую эпоху. Показана важность согласования стратегии и видения компании с мышлением персонала для развития бизнеса в долгосрочной перспективе.

Ключевые слова: управление персоналом, инновационные тенденции, успех в бизнесе, бизнесстратегия, проблемы, оценка эффрективности, соответствующие ресурсы.

Statement of the problem. There are dramatic changes in the business environment in recent years. These changes have had a significant impact on organizational efforts to be successful. In practically every instance, organizations have tried to more clearly identify and then focus on factors that impact their success. One factor that seems to be receiving more attention than any other is the people who work for organizations. What organizations are realizing is that their likelihood of sustained success is most dependent on learning to get the maximum out of their employees. Such a realization has had a significant impact on the practice of human resources management (HRM). What's more, business forecasters predict that the role of employees, managers, and HRM personnel are likely to see more changes in the decades ahead. Thus, individuals entering the business environment today (and tomorrow) require both an understanding of the importance of human resources and effective HRM to organizational success.HR functions like recruitment and selection, legal and political aspects, skill management, global mindset are some of the jostling issues encountered by human resource function.

Analysis of recent research and publications. Theoretical and practical aspects of HR management challenges and trends were investigated by some international authors as: Nigel Guenole, Steve Browne, Erica Keswin, Dan Cannady, JoshBersin. Ukrainian authors as Tetyana Ryabokon, Olga Kucharuk, Lora Gasay, Larysa Onipko, Marianna Yarosh, Evgen Bondarenko have done a significant contribution to the research of HRM issues and modern trends. Therefore, the study of dramatic HRM challenges and implementation of effective trends to reach the organizational success requires further research and development.

The aim of the article. To search for the crucial challenges and innovative trends of effective human resource management in order to improve organizational success.

Presentation of the main research material. A major contributory area to organizational success is the management of workers in organizations. Business success in a market economy is dependent on the optimal utilization of relevant resources such as the financial resources, material resources, and human resources. It is through the combination of these resources that the attainment of the goal is achieved. However, the most significant and complex component for the attainment of organizational success is the human resource. Over a period of time, it has evolved as a strategic function to improve working environment, plan out human resources needs and strike a balance between the organization and employers in order to increase organizational productivity and meet organizational goals. As we move further into the twenty-first century, it's becoming absolutely clear that the effective management of an organization's human resources is a major source of competitive advantage and may even be the single most important determinant of an organization's performance over the long term.

The personnel/human resource department program of each organization is unique, and personnel activities will vary somewhat from firm to firm yet trends clearly indicate that the scope personal responsibilities in increasing in organizations of all sizes. Personnel/Human resource management functions can be described as follows:

1. Job analysis. Job analysis in human resource management (HRM) refers to the process of identifying and determining the duties, responsibilities, and specifications of a given job. It encompasses the collection of data required to put together a job description that will attract the right person to fill in the role. Job analysis in HRM helps establish the level of experience, qualifications, skills and knowledge needed to perform a job successfully. There are next methods of job analysis: interview, questionnaires, observation. By frequently using these three job analysis methods, HR managers, and job analysts can work to improve job specifications, increase professional output and incite company growth.

2. Recruitment and selection. To a great degree, organizational effectiveness depends on the effectiveness of its employees. Without a high quality labor force, an organization is destined to mediocre performance. For this reason, the recruitment of human resource is a critical personnel function. Recruiting and selecting a quality 
labor force involves a variety of personnel activities, including analysis at the labor market, long term planning, interviewing, and testing. Recruiting individuals to fill particular posts within a business can be done either internally by recruitment within the firm, or externally by recruiting people from outside.

3. Appraisal Training and Development. Performance appraisal is a process of evaluating employees work performance over a given period of time. Coens \& Jenkins (2000) suggest that performance appraisal is a mandated process in which, for a specified period of time, all or a group of an employee's work behaviors or traits are individually rated, judged, or described by a rater, and the results are kept by the organization [1]. The most important performance appraisal issue faced by organizations is the perceived fairness of the performance review and the performance appraisal system (Bretz, Milkovich\& Read, 1992). Their findings suggested that most employees perceive their performance appraisal system as neither accurate nor fair [2].

4. Compensation and benefits. Compensation and benefits refers to the compensation/salary and other monetary and non-monetary benefits passed on by a firm to its employees. Compensation and benefits is an important aspect of HRM as it helps to keep the workforce motivated. It helps give benefits to employees based on their performance and actions and brings the best out the employees at the workplace. There can be several ways where benefits can be given to employees. According to the chart below, there are top 5 Ukrainian fields with the highest salaries and their dynamics from April 2018 to April 2019. The one of the most expensive workforce is IT nowadays. The salary of Ukrainian
IT in 2019 has been increased in $25 \%$ comparing to 2018 [3]. Thus, IT sphere has attracted 159687 workers in 2019, which is $26 \%$ more comparing to 2018. Therefore we can see the straight (Fig. 1) correlation between compensation as salary and number of labor which has been involved in the industry.

5. Employee relations. Employees are the major assets of an organization. It is essential that the employees perform together as a collective unit and contribute equally towards the realization of a common goal. Labor unions exert a powerful force upon employees and influence personnel policies and programs for union employees. Because union participation in personnel decision making may have great impact on the economic condition of the firm, managers must understand a union's philosophies and goal and explore ways in which a cooperative rather than an adversarial relationship may be achieved. Many personnel problems are costly and impede on the organization's productivity rate. Modern personnel administrators must create strategies to resolve these problems and to do so they must possess a complete understanding of the research process.

It is really a huge challenge to understand the psychology of workforce, retain the best talents of the industry, motivate them to perform better and handle diversity while maintaining unity simultaneously, especially in countries like Ukraine, where it is still evolving. Globalization has resulted in many positive developments but it has left many concerns for HR managers.

In today's tough world and tight job market, coordinating a multicultural or diverse workforce is a real challenge for HR department. HRM can really support the organization to reach a success. Some

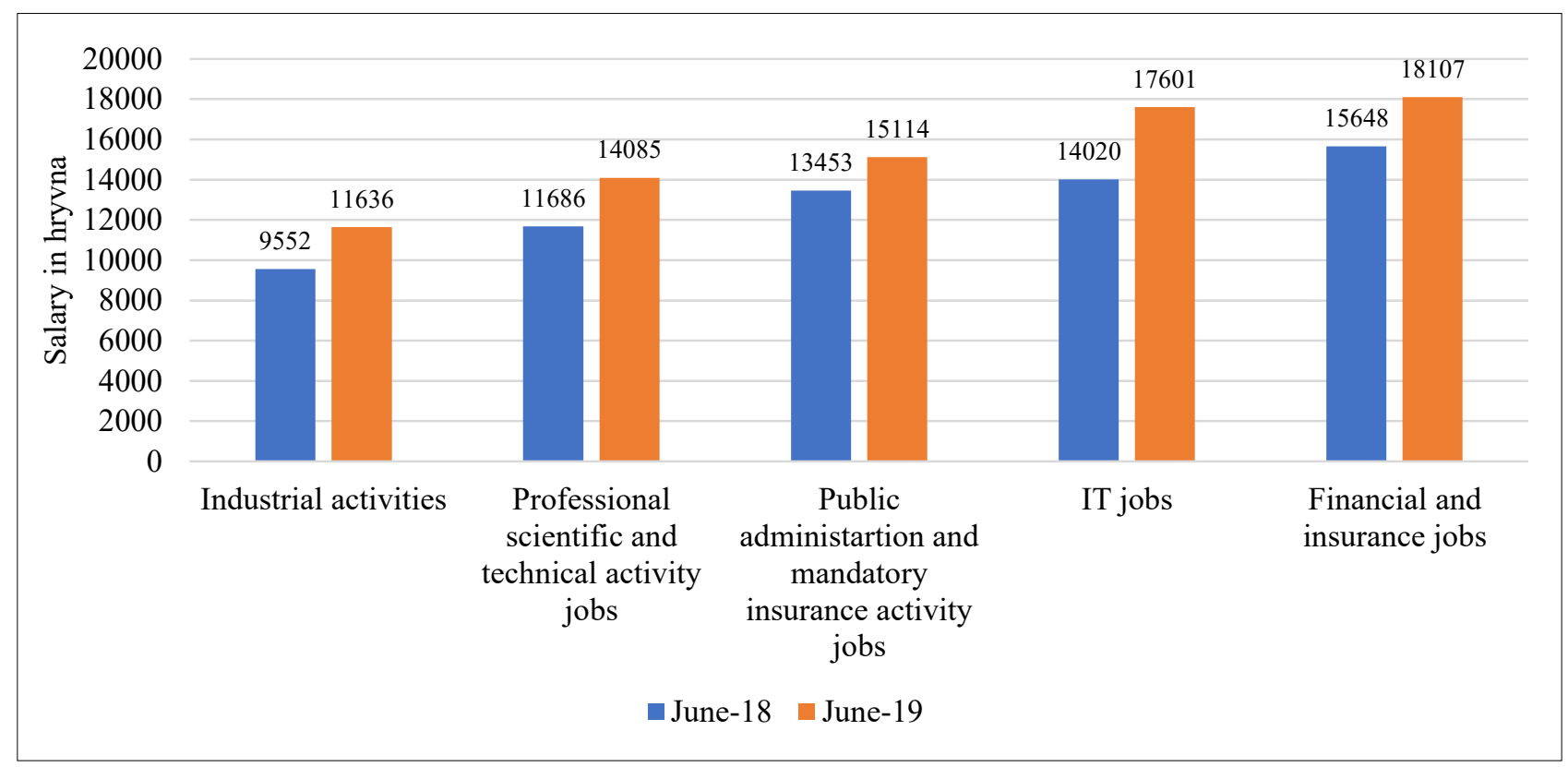

Fig. 1. The salary dynamics among TOP 5 industries in Ukraine [3] 
crucial mistakes can lead to a company recession or on the contrary, the wise management is able to rocket the revenue of the firm. Here are some numbers from the worldwide research to show the importance of human resource department in organizational success:

- three hundred billion dollars is wasted in American business when there is a lack of motivation and emotional contribution;

- there is $20 \%$ difference in shareholders' cost in companies with high and low staff commitment;

- it's $27 \%$ more of revenue in the organizations with the high level of members contribution to the business:

- the companies with positive thinking mentality of the workers are $27 \%$ ahead in sales;

- the company Zappos.com is evaluated in 1.2 billion dollars, using happiness as a business model and bought by Amazon.com. The productivity of the company has been rocketed in $37 \%$ due to the happiness among the staff. [4]

From the experts' opinions, below are HR challenges what companies could face in 2020:

1) Finding, retaining and growing the right talent for the future success of the organization. As the business environment only grows more complex, with entire industries disrupted by technology and regulation, coupled with looming and widescale demographic shift, the competition will only increase. Only organizations that develop a strong employer brand, leverage technology and foster a culture of innovation will be able to attract top talent in their industries. According to the surveys, $53 \%$ are not engaged at work, $46 \%$ of $18-25$-yearolds are likely to bail on a job, and $59 \%$ of employees will leave if they get a better offer. It means that fewer people these days are working just for a paycheck. They want to enjoy their days, and not just on their days off. Employees want to interact with interesting co-workers and customers, they want to learn and enjoy new experiences and yes, they want to have fun at work. A job that doesn't provide a positive, stimulating atmosphere will likely only hold the attention of your new hires for the short term. Finding out what your crew (your employee demographic) wants and offering what you can, is crucial

2) Aligning business strategy with HR. The purpose of HR strategies is to articulate what an organization intends to do about its human resource management policies and practices now and in the longer term. HR strategies may set out intentions and provide a sense of purpose and direction, but they are not just long-term plans. Because all organizations are different, all HR strategies are different. Some strategies are simply very general declarations of intent. When considering how to integrate business and HR strategies it should be remembered that business and $\mathrm{HR}$ issues influence each other and in turn influence corporate and business unit strategies. An illustration of how HR strategies could fit with one or other of the competitive strategies is mentioned below, listed by Porter.

3) Generations conflict. Keeping high talented Gen-X,Y,Z at the contemporary workplace. It requires a shift of mindset. Today, attracting dedicated, skilled and enthusiastic employees is more of a challenge than ever before. Millennials, for example, and increasing numbers of all other working-age generations, are not interested in just getting a job. They won't even settle for just a career. And it isn't all about money, either. The HR game has become much more complex, requiring more strategy, creativity and applied psychology than ever before. Every few decades, a new generation emerges and is thoroughly researched so the world can better understand who they'll be dealing with as younger employees exit university and enter the workforce. And each generation has incredible value to offer organizations at any stage. The modern-day workplace has completed a period of evolution - more so with the inclusion of mobile-centric work trends and other ideologies. This evolution has jarred transitions when it comes to the older workers who are used to getting evaluated based on the hours they put in. The idea of work-life balance is pretty important for Generation $\mathrm{Y}$, with older generations of employees concentrating more on traditional values such as staying behind to work outside of working hours. Leaders need to acknowledge every section of their workforce in order to keep everybody inspired.

4) Need for a digital expertise. Few organizations have yet to realize enterprise-wide digital transformation fully. They simply lack the talent to leverage new technologies and drive organization-wide change fully. Organizations and even entire industries must digitally transform over the next decade to ensure their continuity. Developing digital natives to enter the leadership ranks must be a priority to ensure organizations have strategic plans for digital transformation and an organizational culture that will support it.

5) Remote HR. With increasing globalization, another major challenge that will require our attention is how to manage a remote workforce. Organizations and leaders will have to learn how to leverage employees where and when they are most productive and impactful. Managing people from a distance is a new skill today's managers and leaders will have to develop. Future HR department will have to become an enabler to support executives both by training and providing automation/tools. Having the option of working remotely is also a selling point for a business and could promote employee retention as well as attracting new, bright minds who like the concept of more freedom around how and where they work. The number of remote workers has nearly tripled over an 8 year period to 2019 [6].

What would be the best ideas to improve HR practice nowadays? There is a research into the HRM practices which has revealed a set of 
Table 1

Strategies of the business [5]

\begin{tabular}{|c|c|c|c|}
\hline \multirow[b]{2}{*}{ HR strategy } & \multicolumn{3}{|c|}{ Competitive strategy } \\
\hline & $\begin{array}{l}\text { Achieve competitive } \\
\text { advantage through } \\
\text { innovation }\end{array}$ & $\begin{array}{l}\text { Achieve competitive } \\
\text { advantage through quality }\end{array}$ & $\begin{array}{l}\text { Achieve competitive } \\
\text { advantage through } \\
\text { cost-leadership }\end{array}$ \\
\hline Resourcing & $\begin{array}{l}\text { Recruit and retain high } \\
\text { quality people with } \\
\text { innovative skills and } \\
\text { a good track record in } \\
\text { innovation } \\
\end{array}$ & $\begin{array}{l}\text { Use sophisticated selection } \\
\text { procedures to recruit people } \\
\text { who are likely to deliver } \\
\text { quality and high levels of } \\
\text { customer service }\end{array}$ & $\begin{array}{l}\text { Develop core/ periphery } \\
\text { employment structures; recruit } \\
\text { people who are likely to add } \\
\text { value; if unavoidable, plan and } \\
\text { manage downsizing humanely }\end{array}$ \\
\hline $\begin{array}{l}\text { Learning and } \\
\text { development }\end{array}$ & $\begin{array}{l}\text { Develop strategic } \\
\text { capability and provide } \\
\text { encouragement and } \\
\text { facilities for enhancing } \\
\text { innovative skills and } \\
\text { enhancing the intellectual } \\
\text { capital of the organization }\end{array}$ & $\begin{array}{l}\text { Encourage the development } \\
\text { of a learning organization, } \\
\text { develop and implement } \\
\text { knowledge management } \\
\text { processes, support total } \\
\text { quality and customer care } \\
\text { initiatives with focused } \\
\text { training }\end{array}$ & $\begin{array}{l}\text { Provide training designed } \\
\text { to improve productivity; } \\
\text { inaugurate just-in-time training } \\
\text { which is closely linked to } \\
\text { immediatebusiness needs } \\
\text { and can generate measurable } \\
\text { improvements in cost- } \\
\text { effectiveness }\end{array}$ \\
\hline Reward & $\begin{array}{l}\text { Provide financial } \\
\text { incentives and rewards } \\
\text { and recognition for } \\
\text { successful innovations }\end{array}$ & $\begin{array}{l}\text { Link rewards to quality } \\
\text { performance and the } \\
\text { achievement of high } \\
\text { standards of customer service }\end{array}$ & $\begin{array}{l}\text { Review all reward practices to } \\
\text { ensure that they provide value } \\
\text { for money and do not lead to } \\
\text { unnecessary expenditure }\end{array}$ \\
\hline
\end{tabular}

rehearsals that are followed in the international companies.

Some best practices are mentioned below:

Reducing time to hire. All the recruiters desire to hire high quality employees quickly in order to reduce the cost of a process and waste of productivity. According to the huge companies as Hilton and Google, there are few approaches to shorten a process:

- video interviews to speed up screening and interviewing. Using on-demand digital interview platform Hirevue, Hilton found it can interview multiple candidates at once-without a recruiter being present. Candidates can be interviewed at home and at a time that works for them by signing into the platform on their phone or computer and going through the built-in list of questions. Not only does the platform allow for convenient video interviews, it also includes artificial intelligence (AI) features that evaluate candidate communication skills and non-verbal gestures. For customer service roles, Hilton's recruiters can even use simulations to test how a candidate will react to an angry customer. The results of this new approach were staggering: after implementing video interviews, Hilton's time to hire dropped from 42 days to just five. The strategy also streamlined executive hiring, allowing leaders from various offices around the world to join remote panel interviews easily.

- a "Rule of Four" to avoid needless interviews. Google implemented a "Rule of Four" standard for most of its interviews. Using a maximum of four interviews, the company cut its time to hire by about two weeks - making the process less stressful for candidates and saving many hours of employee time. Four interviewers were enough to predict a new hire's performance with $86 \%$ percent confidence at Google. After the fourth interview, the accuracy of the employee recruitment success increases by less than 1 percent.

High motivation of employees. Growing numbers of job satisfactions and organization efficiency is the result of human resource motivation. Maintaining the level of motivation of employees in the organization is varied from other activities carried out in the organization and depends on the type of project. It is mentioned that work satisfaction and also motivation are considered various in human resources. Motivation is the strength of the people to make them able to choose specific work, to stay and work hard in the given position. The value of motivating employees is significant at all level of any organization. This is further explain how an organization motivation is a necessary part for the human resources, beginning from the organization manager must have knowledge and factor influence on the motivation of his sub employees to expect from them to perform well in the organization, goes through the employees to know expectations from their manager in work place end on the professional of human resources who has priority to motivate employee with well design learning and training system. Kovach, (1980) found that companies/ organization more like to have motivated and energetic employees rather than the person with high education but lack of energy [7]. However, due to the different and difficult faces of human behavior, it is not an easy job to motivate all of them according to the job expectations. Past studies showed that the major tool adopted to motivate employees was to offer them extra salary or incentives, nevertheless, there are other tools to keep labor motivated. Following are the important motivation factors found in the previous study of human resources management and these tools 
frequently use in human resources management to motivate employees in organizations [8]:

1. Sufficiency wage;

2. Job Security;

3. Interesting Work;

4. Promotion and growth in the organization;

5. Full appreciation of work done;

6. Open communication;

7. Participation in goal setting;

8. Feeling of being well informed and involved;

9. Freedom to plan and execute work independently;

10. A Good match between your job requirements and your Abilities and Experience;

11. A good working condition (such as light, temperature, cleanliness, low noise level)

HR should think like a marketer. "According to Josh Bersin, the employer's brand is a reflection the company's leadership style and organizational culture. All these things are interconnected, and the way they resonate will be directly affect the organization's ability to hire people" [5]. HR will develop "internal marketing", the role of which includes the coordination of social marketing and brand" [9]. Melissa Bailey, President of Americas for Universum, says that by $2020 \mathrm{HR}$ will make a powerful transition from the recruitment process.

Social networking. Recently, wider development gets the term social recruitment which implies interaction with potential candidates through the social networks. Such interaction can be implemented differently by many ways: creating a specialized group, placement and repost of organization vacancies, business correspondence in social networks, promotion of the brand, attracting existing employees in actively promoting the values of the organization in social networks. Very often, this tool is not considered at all, either meets a sharply negative attitude from organization leadership. The fact is that many managers are afraid of a negative assessment of organizations in the online community. However, management should think that in any case of whether the organization uses social nets or not, company personnel would share their opinions online. That's why focused work with social network is necessary. It will form a positive image personnel management services, will provide an opportunity culturally, constructively and in a timely manner, will take into account the emerging negative feedbacks [10]. There is an opportunity to expand the range of potential social candidates - to take a new level search and selection of personnel.

Developing Trust. Companies are always looking for ways to improve employee productivity, and they can learn from high-performing organizations. Companies like Apple, Google, and Netflix are $40 \%$ more productive than the average company by using a mix of employee performance management strategies that focus on organizational structure and trust-building. According to the research of Bain \& Company, the way companies construct their teams has a major impact on productivity.
Apple and Google, for example, dedicate 95 percent of their top talent to key business functions, as opposed to spreading top talent across many areas. Mankins also pointed out that extending trust to employees improved productivity and supported employee growth and development at top companies. He said organizational rules and processes often prevent people from getting things done or improving in their role. Netflix avoids a common process issue, expense management, by trusting its employees. The company has no expense policy. Instead, it trusts employees to act responsibly.

Analytics of people satisfaction at the work place. People analytics will no longer be a nice-tohave, and it will be an indispensable aspect of running a business. As companies try to improve their ability to lead people, they are relying on data to provide insights that can help with issues like productivity and employee engagement. Regardless of how well-meaning a company's performance intentions, analytics can show what a company's results really are. This can be a very useful mirror, particularly when companies want to tackle issues like diversity and pay equity. As companies can collect more and better data on turnover, team interaction, wellbeing, and employee feedback, managers can make more informed decisions and improve the overall employee experience.

Job crafting. When you allow employees to do what they do best, it makes your team more innovative and productive. Research shows that $60 \%$ of employees want the ability to do what they do best, regardless of their role. They are driven by purpose and managers who actively promote their development. Companies will move to what's called "job crafting" which is job roles built around an employee's strengths and interests. Learning and development. Look for companies to respond to this need by providing an employee with more training and development opportunities, but not the traditional kind. Organizations are moving toward micro-learning, which is short, informal, self-directed and mobile-optimized content on single topics. These can be brief videos, webinars, podcasts, or even games that provide learning materials in an easy-to-absorb format. Employee training software also puts staff in control of their development so that they can add to their skillset with on-demand content. Training software makes learning more continuous and engaging.

Implementing HR scorecards. HR scorecards are the tools to measure how well the HR function is aligned to the overall strategic goals of the organization. In other words, HR now was expected to align its recruitment, compensation, and employee retention strategies to the organizational strategies. What this means is that in contemporary organizations, the HR managers have to be aligned with the larger organizational strategies. Towards this end, the HR Scorecard works by providing decision-makers with data and inputs about how much the employee recruitment and retention processes 
cost and what are the benefits of the same. For much of the 20th century, it was commonly understood that these costs are part of the overall organizational costs and there was no way to measure the benefits of such expenses in "tangible" ways. In other words, what this means is that an HR Scorecard provides the organizational leaders with metrics and data in tangible terms about the payoffs and the benefits from HR processes and activities.

Benchmarking. HR benchmarking can provide some useful and quite powerful information. When looking at similar organizations, a lot can be determined through benchmarking comparisons. HR pros can see where gaps exist within certain practices. Which policies are working well and which problems may be causing can be also identified as well as issues within such areas as hiring, training, and promotion. Specific issues such as sick time, retention and discipline can be examined separately. This is helpful when attempting to identify patterns for future use [11].
Conclusions. In conclusion, the practice of HRM needs to be integrated with the overall strategy to ensure effective use of people and provide better returns to the organizations in terms of ROI (Return on Investment) for every hryvnia or dollar spent on them. Unless the HRM practice is designed in this way, the firms stand to lose from not utilizing people fully. And this does not bode well for the success of the organization.

As more organizations integrate employee performance management trends and adopt best HR practices of ongoing conversations, employee recognition, and reforming their annual performance review process, managers will build authentic work relationships and nurture employee development and growth.

Ultimately, organizations won't just produce positive business outcomes; by helping their employees realize their best selves, they will create a more positive impact for customers, managers, investors, and the world at large.

\section{REFERENCES:}

1. Coens A. T., \&Jenkins, M. (2000), Abolishing performancea ppraisals. SanFrancisco, CA: Berret- KoehlerPublishers, Inc.

2. Bretz R., Milkovich, G.T. andRead, W.H. (1992), "The current state of performance appraisal research and practice: concerns, directions and implications", Journal of Management, Vol. 18, pp.111-137.", Journal of Management, Vol. 18, pp.111-137.

3. Макроекономічний огляд та прогноз. Міністерство фрінансів України. 2019. № 8. C 9. URL: https://mof.gov.ua/storage/files/Macroeconomic_outlook_MFU_August_2019_ua.pdf (дата звернення 10 жовтня 2019 року).

4. Осадчук E. Помогает ли HR зарабатывать бизнесуилитолькотратитденьгикомпании? Форум DOU. 2017 URL: https://dou.ua/lenta/columns/hr-expenses-or-earnings-2/ (дата звернення: 10 жовтня 2019).

5. Porter M E (1985) Competitive Advantage: Creating and sustaining superior performance, New York, The Free Press.

6. Osterhaus E. The HR Department of 2020: 6 bold predictions URL:http://new_talent_times.softwareadvice. com/the_hr_department_of_2020_413/(дата звернення: 10 жовтня 2019).

7. Kovach (1987). What motivate employees? workers and supervisor perception and difference. Business Horizons.

8. Kirstein M. (2010). The role of motivation in human resources: importance of motivation factors among future business persons. Aarhus : Denmark

9. Muhammad F. HR 2020 - The future of HR practices. URL: http://www.hr_portal.ru/article/15_hr_trendov_2014_goda?page $=0$ (дата звернення: 10 жовтня 2019).

10. Ryan C. Williams. Social recruiting for Dummies, Hoboken, New Jersey, 2013, 44 p.

11. Бенчмаркинг.URL:https://ru.wikipedia.org/wiki/Бенчмаркинг/ (дата звернення: 10 жовтня 2019).

\section{REFERENCES:}

1. Coens A. T., \&Jenkins, M. (2000), Abolishing performancea ppraisals. SanFrancisco, CA: Berret- KoehlerPublishers, Inc.

2. Bretz R., Milkovich, G.T. andRead, W.H. (1992), "The current state of performance appraisal research and practice: concerns, directions and implications", Journal of Management", Journal of Management, vol. 18, pp. 111-137.

3. Makroekonomi'chnij oglyad ta prognoz. Mi ni sterstvo fi'nansi`v Ukrayini [Macroeconomic review and forecast. Ministry of Finance of Ukraine]. 2019. no. 8. pp. 9. Available at: https://mof.gov.ua/storage/files/Macroeconomic_outlook_MFU_August_2019_ua.pdf (accessed 10 October 2019).

4. О̄садчук Е. (2017) Pomogaet li HR zarabaty`vat' biznesu ili tol'ko tratit den`gi kompanii? [Does HR help make a business, or does it just spend company money?]. Available at: https://dou.ua/lenta/columns/hr-expenses-or-earnings-2/ (accessed 10 October 2019).

5. Porter M. E. (1985) Competitive Advantage: Creating and sustaining superior performance, New York, The Free Press. 
6. Osterhaus E. (2017) The HR Department of 2020: 6 bold predictions. Available at: http://new_talent_times. softwareadvice.com/the_hr_department_of_2020_413/ (accessed 10 October 2019).

7. Kovach (1987). What motivate employees? workers and supervisor perception and difference. Business Horizons.

8. Kirstein M. (2010). The role of motivation in human resources: importance of motivation factors among future business persons. Aarhus : Denmark

9. Muhammad F. (2018) HR 2020 - The future of HR practices. Available at: http://www.hr_portal.ru/article/15_ hr_trendov_2014_goda?page $=0$ (accessed 15 October 2019).

10. Ryan C. (2013) Williams. Social recruiting for Dummies, Hoboken, New Jersey, 2013, p. 44.

11. Benchmarking. [Benchmarking]. Available at: https://ru.wikipedia.org/wiki/Бенчмаркинг/ (accessed 15 October 2019). 